\title{
Villous Capillary Lesions Of Placenta: A Ten-Year Experience With Brief Review Of Literature
}

\author{
Niraimathi Manickam $^{1 *}$, Renu G'boy Varghese ${ }^{1}$, Manjiri Pansalkar ${ }^{1}$, Anita Ramdas ${ }^{1}$ and Mary Daniel ${ }^{2}$ \\ ${ }^{1}$ Department of Pathology, Pondicherry Institute of Medical Sciences, Puducherry, India \\ ${ }^{2}$ Department of Obstetrics and Gynecology, Pondicherry Institute of Medical Sciences, Puducherry, India
}

\begin{abstract}
Background: Villous capillary (VC) lesions of placenta range from reactive to benign tumors such as chorangiosis $(\mathrm{CH})$, chorangiomatosis $(\mathrm{CM})$ and chorangioma (CA). Associated with perinatal morbidity and mortality, these rare lesions are documented with maternal, placental and fetal risk factors. The aim of this study was to analyze the clinico-pathological profile of VC lesions of placenta and to compare the associated risk factors between $\mathrm{VC}$ lesion $(\mathrm{CH})$ and those with no $\mathrm{VC}$ lesions.

Methods: This retrospective study includes all the VC lesions of Placenta diagnosed in Pondicherry Institute of medical sciences from January 2006 to February 2016. For comparison, gestational age matched controls with no VC lesions were obtained. Chi-square test or fischer's exact test was used for statistical analysis.

Results: Of $29 \mathrm{VC}$ lesions of placenta (5.6\%) in 10 years, 27 were $\mathrm{CH}$. Commonly associated feto-maternal factors include anemia (47.4\%), oligohydramnia (33.3\%), infection (28.6\%), pre-eclampsia (23.8\%), NICU admission $(47.8 \%)$, fetal growth retardation (17.4\%), congenital anomaly $(17.4 \%)$, intrauterine death $(13 \%)$. When compared with controls, $\mathrm{CH}$ had significantly increased LSCS, premature rupture of membranes and histologically, chorioamnionitis and funisitis that support its infective etiology. One case of CA associated with IUGR, polyhydramnios was found to have $\mathrm{CH}$ in her next pregnancy which points to a possibility of genetic predisposition among VC lesions. CM was diagnosed in primi with severe pre-eclampsia and asymmetric IUGR.
\end{abstract}

Conclusion: Prevalence of $\mathrm{CH}$ is $5.2 \%$. VC lesions of placenta are commonly associated with complicated pregnancy and neonatal morbidity.

Keywords: Villus Capillary Lesions; Chorangiosis; Chorangioma; Chorangiomatosis

\section{Introduction}

Placenta is a highly vascular, hemostatic organ derived from both maternal and fetal structures. Any complications, pre or post placental will get reflected on placental tissue that can easily be examined by light microscopy. One such condition is the villous capillary (VC) lesions of placenta that include chorangiosis $(\mathrm{CH})$, chorangiomatosis $(\mathrm{CM})$ and chorangioma (CA). These are interrelated conditions ranging from reactive to benign tumors. ${ }^{[1]}$ They correlate with significant perinatal morbidity and mortality because of their associated maternal, fetal and placental risk factors. ${ }^{[2]}$ These rare lesions are less widely studied except for few case reports.

The objective of this study is to document the clinicopathological features of $\mathrm{VC}$ lesions of placenta and to compare the associated risk factors between cases with $\mathrm{VC}$ lesions and those with no VC lesions.

\section{Materials and Methods:}

This retrospective record based study was carried out in the department of pathology, Pondicherry institute of medical sciences, Pondicherrry. All the cases diagnosed as chorangiosis $(\mathrm{CH})$, chorangioma (CA) and chorangiomatosis $(\mathrm{CM})$ by histopathological examination from January 2006 to February 2016 were included in the study. The clinical details were retrieved from available case files and request forms. To know the significant clinical associations of $\mathrm{VC}$ lesions of placenta from those with no VC lesion, gestational age matched controls were obtained for comparison. Only $\mathrm{CH}$ cases were studied for comparative analysis, as CA and CM were too less in number.

$\mathrm{CH}$ is diagnosed as per Altshuler's criteria which " when inspection with a $\times 10$ objective showed 10 villi each with 10 or more vascular channels in 10 or more non-infarcted, non-ischemic zones of atleast three different placental areas". ${ }^{[2]}$ Normally terminal villus has 2 to 6 capillary vessels even when represented twice in the section. ${ }^{[3,4]}$ $\mathrm{CM}$ is characterized by increase in villous capillaries that permeates normal villous structure. CA is a neoplastic proliferation of capillaries and stroma within a villous forming an expansile nodular lesion. ${ }^{[1]}$

For statistical analysis, Chi square test or Fischer's exact test was done using SPSS software to find the significant 
variables between VC lesions and no VC lesions. P-value less than 0.05 was taken as statistically significant.

\section{Results}

There were total of 14,308 deliveries during the study period of 10 years, out of which 520 placentas (3.6\%) were sent for histopathological evaluation. Among 520 placentas, Villous capillary (VC) lesions were diagnosed in $29(5.6 \%)$ with $27(5.2 \%)$ showing Chorangiosis $(\mathrm{CH})$ and one each of Chorangioma (CA) and Chorangiomatosis (CM).

Majority of patients with $\mathrm{CH}$ were primi $(15 / 25,60 \%)$ aged between 22 and 41 years who delivered at more than 34 weeks $(20 / 22,90.9 \%)$ by lower segment cesarean section (LSCS), of which most had emergency LSCS $(14 / 16,87.5 \%)$. The most common clinical associations include maternal anemia and increased number of neonatal intensive care unit (NICU) admissions. Histologically, chorioamnionitis was seen in majority of placenta with $\mathrm{CH}$.

Table 1 compares the clinical associations between $\mathrm{CH}$ and Non-VC lesions of placenta. Total number of deliveries by LSCS, premature rupture of membrane (PROM) and histological features of chorioamnionitis, funisitis were significantly higher in $\mathrm{CH}$ when compared to controls.

There was one case each of CM and CA in this study. CM was diagnosed in a 26-yr-old hypothyroid primi at term gestation with severe pre-eclampsia, intrauterine growth retardation (IUGR). She delivered a $1.7 \mathrm{~kg}$ male baby. Placenta showed features of diffuse multifocal CM with areas of infarction and calcification.

The other case was 22-year-old primi with polyhydramnios and severe IUGR, delivered a $1.8 \mathrm{~kg}$ male baby by LSCS at 36 weeks. Antenatal USG at 34 weeks revealed two hypoechoic lesions in placenta, suggestive of $\mathrm{CH}$. Grossly placenta showed two nodular mass measuring $7.5 \times 6.5 \times 4.5$ and $10.5 \times 7 \times 6$, one with attached pedicle. Histology showed $\mathrm{CA}$ in both nodules with evidence of infarction in one of them (previously published as a case report from our institute). ${ }^{[5]}$ Interestingly, in her next pregnancy placenta showed evidence of $\mathrm{CH}$. She was admitted at 38 weeks then with leaking per vaginum and underwent emergency LSCS for non-progression of labour and brow presentation.

Table 1: Comparison of clinical and histological associations between Chorangiosis (CH) and non-Villous capillary lesions.

\begin{tabular}{|l|c|c|c|c|c|}
\hline VARIABLES & $\begin{array}{c}\text { Villous capillary } \\
\text { lesion } \mathbf{( C H )}\end{array}$ & $\%$ & $\begin{array}{c}\text { Non-Villous } \\
\text { capillary lesions }\end{array}$ & $\%$ & p value \\
\hline ANTENATAL VARIABLES: & $\mathrm{n}=27$ & & $\mathrm{n}=42$ & & \\
\hline Number of Primi gravida & 15 (of 25) & 60 & 20 & 47.6 & 0.520 \\
\hline Number of twin pregnancy & 2 & 7.4 & 5 & 11.9 & 0.69 \\
\hline Number of LSCS & 16 (of 22) & 72.7 & 19 & 45.2 & 0.036 \\
\hline MATERNAL FACTORS: & $\mathrm{n}=21$ & & $\mathrm{n}=42$ & & \\
\hline Anemia & 9 (of 19) & 47.4 & 16 (of 39) & 41 & 0.770 \\
\hline Oligohydramnios & 7 & 33.3 & 11 & 26.2 & 0.554 \\
\hline Fever \&/ infection & 6 & 28.6 & 6 & 14.3 & 0.173 \\
\hline Premature rupture of membrane & 5 & 23.8 & 2 & 4.8 & 0.02 \\
\hline Pre-eclampsia & 5 & 23.8 & 5 & 11.9 & 0.28 \\
\hline Gestational Diabetes Mellitus & 3 & 14.3 & 7 & 16.7 & 0.806 \\
\hline Hypothyroidism & 2 & 9.5 & 4 & 9.5 & 0.465 \\
\hline FETAL FACTORS: & $\mathrm{n}=23$ & & $\mathrm{n}=47$ & & \\
\hline NICU admissions & 11 & 47.8 & 17 & 36.2 & 0.350 \\
\hline Congenital anomaly & 4 & 17.4 & 3 & 6.4 & 0.149 \\
\hline Intrauterine growth retardation (IUGR) & 4 & 17.4 & 8 & 17 & 0.9 \\
\hline Intrauterine death & 3 & 13 & 16 & 34 & 0.06 \\
\hline HISTOLOGICAL FEATURES: & $\mathrm{n}=29$ & & $\mathrm{n}=47$ & & \\
\hline Chorioamnionitis & 11 & 37.9 & 5 & 10.6 & 0.005 \\
\hline Calcification & 9 & 31 & 28 & 59.6 & 0.016 \\
\hline Infarction & 6 & 20.7 & 13 & 27.7 & 0.750 \\
\hline Funisitis & 2 & 6.9 & 0 & 0 & 0.036 \\
\hline
\end{tabular}


Table 2: Various studies and case reports on risk factors associated with Chorangiosis (CH).

\begin{tabular}{|c|c|c|c|c|}
\hline $\begin{array}{l}\text { Author, year, no. of } \\
\text { cases }\end{array}$ & Maternal factors & Fetal factors & Placental factors & Histology \\
\hline $\begin{array}{l}\text { Franciosi et al, }{ }^{[8]} 1999, \\
n=2\end{array}$ & LSCS & $\begin{array}{l}\text { Fetal distress, } \\
\text { Intrauterine death (IUD) }\end{array}$ & $\begin{array}{l}\text { Abruptio placenta, } \\
\text { Tight nuchal cord }\end{array}$ & $\mathrm{CH}$ \\
\hline $\begin{array}{l}\text { Ogino et al, }{ }^{[1]} 2000, \\
n=46\end{array}$ & $\begin{array}{l}\text { Diabetes, Pre- } \\
\text { eclampsia, Multiple } \\
\text { pregnancy }\end{array}$ & $\begin{array}{l}\text { IUGR, congenital } \\
\text { anomaly }\end{array}$ & Placentomegaly & $\begin{array}{l}\mathrm{CH} \text {, Delayed villous } \\
\text { maturation, Villitis of } \\
\text { unknown etiology }\end{array}$ \\
\hline $\begin{array}{l}\text { Ossa et al, }{ }^{[11]} 2001, \\
n=1\end{array}$ & Pre-eclampsia & - & - & $\mathrm{CH}$ \\
\hline $\begin{array}{l}\text { Gupta et al, }{ }^{[12]} 2006, \\
n=12\end{array}$ & $\begin{array}{l}\text { Syphilis, Pre- } \\
\text { eclampsia, Diabetes, } \\
\text { jaundice }\end{array}$ & $\begin{array}{l}\text { Still born, non-immune } \\
\text { hydrops }\end{array}$ & Abruptio placenta & $\begin{array}{l}\mathrm{CH} \text {, infarction, } \\
\text { calcification }\end{array}$ \\
\hline $\begin{array}{l}\text { Mathew et al, }{ }^{[9]} 2008, \\
n=2\end{array}$ & $\begin{array}{l}\text { Pleural Tuberculosis, } \\
\text { LSCS }\end{array}$ & Fetal distress & Single umblical artery & $\mathrm{CH}$ \\
\hline $\begin{array}{l}\text { Agale et al, }{ }^{[7]} 2009 \\
n=3\end{array}$ & $\begin{array}{l}\text { Severe anemia, Pre- } \\
\text { eclampsia, LSCS }\end{array}$ & $\begin{array}{l}\text { IUD, congenital } \\
\text { anomaly, fetal distress }\end{array}$ & Abruptio placenta & $\mathrm{CH}$ \\
\hline $\begin{array}{l}\text { Soma et al, }{ }^{[10]} 2012, \\
n=58\end{array}$ & $\begin{array}{l}\text { LSCS, HELLP } \\
\text { syndrome }\end{array}$ & $\begin{array}{l}\text { Low birth weight, } \\
\text { congenital anomaly, } \\
\text { IUGR, IUD }\end{array}$ & Single umblical artery & $\begin{array}{l}\mathrm{CH} \text {, infarction, } \\
\text { Intervillous thrombosis }\end{array}$ \\
\hline $\begin{array}{l}\text { Malathi et al, }{ }^{[13]} 2014, \\
n=1\end{array}$ & Pre-eclampsia & IUD & - & $\mathrm{CH}$ \\
\hline $\begin{array}{l}\text { Aparna et al, }{ }^{[6]} 2014, \\
n=2\end{array}$ & $\begin{array}{l}\text { Pre-eclampsia, } \\
\text { anemia, LSCS }\end{array}$ & Fetal distress & - & $\mathrm{CH}$ \\
\hline $\begin{array}{l}\text { Srinivasan et al, }{ }^{[3]} \\
2014, n=10\end{array}$ & $\begin{array}{l}\text { Anemia, Diabetes, } \\
\text { hypothyroid, Pre- } \\
\text { eclampsia }\end{array}$ & Not available & - & $\mathrm{CH}$ \\
\hline $\begin{array}{l}\text { Present study, 2016, } \\
n=27\end{array}$ & $\begin{array}{l}\text { LSCS, Anemia, } \\
\text { oligohydramnios, } \\
\text { infection, Pre- } \\
\text { eclampsia, pre- } \\
\text { mature rupture of } \\
\text { membrane, Diabetes, } \\
\text { hypothyroid }\end{array}$ & $\begin{array}{l}\text { Fetal distress, IUGR, } \\
\text { congenital anomaly, } \\
\text { IUD }\end{array}$ & - & $\begin{array}{l}\mathrm{CH} \text {, chorioamnionitis, } \\
\text { calcification, infarction, } \\
\text { funisitis }\end{array}$ \\
\hline
\end{tabular}

Table 3: Various studies and case reports on risk factors associated with Chorangiomatosis (CM).

\begin{tabular}{|c|c|c|c|c|}
\hline $\begin{array}{l}\text { Author, year, no. of } \\
\text { cases }\end{array}$ & Maternal factors & Fetal factors & $\begin{array}{l}\text { Placental } \\
\text { factors }\end{array}$ & Histology \\
\hline $\begin{array}{l}\text { Ogino et al, }{ }^{[1]} 2000 \\
n=39\end{array}$ & $\begin{array}{l}\text { Pre-eclampsia, Multiple } \\
\text { pregnancy, diabetes }\end{array}$ & $\begin{array}{l}\text { IUGR, congenital } \\
\text { anomalies }\end{array}$ & - & $\begin{array}{l}\text { Focal } \mathrm{CM} \text {, segmental CM, } \\
\text { diffuse } \mathrm{CM}\end{array}$ \\
\hline $\begin{array}{l}\text { Chopra et al, }{ }^{[16]} 2006, \\
n=1\end{array}$ & LSCS & $\begin{array}{l}\text { Non-immune hydrops, } \\
\text { intestinal stenosis }\end{array}$ & - & Diffuse Multifocal CM \\
\hline $\begin{array}{l}\text { Bagby et al, }{ }^{[14]} 2010, \\
n=53\end{array}$ & $\begin{array}{l}\text { Advanced age }{ }^{*}, \text { non-primi } \\
\text { gravida* }\end{array}$ & Congenital anomalies $^{*}$ & - & $\begin{array}{l}\text { Diffuse Multifocal CM, } \\
\text { Avascular villi, Distal } \\
\text { villous immaturity }\end{array}$ \\
\hline $\begin{array}{l}\text { Perera et al, }{ }^{[17]} 2011, \\
n=1\end{array}$ & Twin gestation & $\begin{array}{l}\text { IUGR, hydrops, } \\
\text { anemia }\end{array}$ & & Diffuse Multifocal CM \\
\hline $\begin{array}{l}\text { Kalli et al, }{ }^{[15]} 2012, \\
n=1\end{array}$ & $\begin{array}{l}\text { Positive chlamydia } \\
\text { screen }\end{array}$ & $\begin{array}{l}\text { Still born, congenital } \\
\text { anomaly }\end{array}$ & - & Diffuse Multifocal CM \\
\hline $\begin{array}{l}\text { Boroujeni et al, }{ }^{[18]} \\
2014, n=105\end{array}$ & - & $\begin{array}{l}\text { Low birth weight", } \\
\text { NICU }^{*} \text { admission }\end{array}$ & - & $\begin{array}{l}\text { Diffuse Multifocal CM, } \\
\text { focal CM }\end{array}$ \\
\hline $\begin{array}{l}\text { Present study, 2016, } \\
n=1\end{array}$ & Severe pre-eclampsia & IUGR, NICU admission & - & Diffuse Multifocal CM \\
\hline
\end{tabular}


Table 4: Various studies and case reports on risk factors associated with Chorangioma (CA).

\begin{tabular}{|c|c|c|c|c|c|}
\hline $\begin{array}{l}\text { Author, year, no. of } \\
\text { cases }\end{array}$ & $\begin{array}{l}\text { Largest } \\
\text { dimension }(\mathrm{cm})\end{array}$ & Maternal factors & Fetal factors & $\begin{array}{l}\text { Placental } \\
\text { factors }\end{array}$ & Histology \\
\hline Chen et al, ${ }^{[22]} 1997, \mathrm{n}=2$ & 9 & $\begin{array}{l}\text { Polyhydramnios, } \\
\text { preterm labour, } \\
\text { Premature rupture of } \\
\text { membrane }\end{array}$ & $\begin{array}{l}\text { Anemia, } \\
\text { thrombocytopenia, } \\
\text { hemangiomatosis }\end{array}$ & - & $\begin{array}{l}\text { CA with } \\
\text { mesenchym- } \\
\text { al hyperplasia }\end{array}$ \\
\hline Ogino et al, ${ }^{[1]} 2000, n=36$ & Not available & $\begin{array}{l}\text { Multiple pregnancy, } \\
\text { Pre-eclampsia }\end{array}$ & $\begin{array}{l}\text { IUGR, cong } \\
\text { anomalies }\end{array}$ & $\begin{array}{l}\text { Placenta }<10^{\text {th }} \\
\text { percentile } \\
\text { weight }\end{array}$ & $\begin{array}{l}\text { Nodular CA, } \\
\text { multi-nodular } \\
\text { CA } \\
\end{array}$ \\
\hline Lez et al, ${ }^{[23]} 2010, n=1$ & 7 & - & - & - & CA \\
\hline Adil et al, ${ }^{[20]} 2012, n=1$ & 13 & $\begin{array}{l}\text { Pre-eclampsia, } \\
\text { LSCS }\end{array}$ & Low birth weight & - & CA \\
\hline $\begin{array}{l}\text { Kodandapa-ni et al, }{ }^{[19]} \\
\text { 2012, } n=1\end{array}$ & 12 & $\begin{array}{l}\text { Polyhydramnios, } \\
\text { preterm labor }\end{array}$ & $\begin{array}{l}\text { Low birth weight, } \\
\text { died of DIC }\end{array}$ & - & $\mathrm{CA}$ \\
\hline Tihonenko I, ${ }^{24]}$ 2012, n=1 & 3 & - & $\begin{array}{l}\text { Hydrops, cardiac } \\
\text { failure, anemia }\end{array}$ & - & Multiple CA \\
\hline $\begin{array}{l}\text { Lokuhatty et al, }{ }^{[25]} 2014 \text {, } \\
n=1\end{array}$ & 13 & $\begin{array}{l}\text { Polyhydramnios, } \\
\text { preterm labor }\end{array}$ & $\begin{array}{l}\text { IUGR, breech, } \\
\text { NICU admission }\end{array}$ & - & $\begin{array}{l}\text { CA with } \\
\text { ischemic } \\
\text { necrosis } \\
\end{array}$ \\
\hline Andola et al, ${ }^{[26]} 2014, n=4$ & 23 & $\begin{array}{l}\text { Preterm delivery, } \\
\text { polyhydramnios, } \\
\text { Pre-eclampsia } \\
\end{array}$ & $\begin{array}{l}\text { IUGR, Intra uterine } \\
\text { death }\end{array}$ & $\begin{array}{l}\text { Abruptio } \\
\text { placenta }\end{array}$ & $\mathrm{CA}$ \\
\hline $\begin{array}{l}\text { Abdalla et al, }{ }^{[27]} 2014, \\
n=1\end{array}$ & 5 & $\begin{array}{l}\text { Polyhydramnios, } \\
\text { anemia }\end{array}$ & - & - & $\mathrm{CA}$ \\
\hline $\begin{array}{l}\text { Srinivasan et al, }{ }^{[3]} 2014, \\
n=2\end{array}$ & 2.5 & $\begin{array}{l}\text { Pre-eclampsia, } \\
\text { anemia }\end{array}$ & Not available & - & CA \\
\hline Singh et al, ${ }^{[28]} 2015, n=1$ & Not available & Polyhydramnios & IUGR & - & $\mathrm{CA}$ \\
\hline Sahu et al, ${ }^{[29]} 2016, n=1$ & 7 & Polyhydramnios & - & - & $\begin{array}{l}\text { CA with } \\
\text { infarction } \\
\end{array}$ \\
\hline Present study, 2016, n=1 & 10.5 & $\begin{array}{l}\text { Polyhydramnios, } \\
\text { LSCS }\end{array}$ & $\begin{array}{l}\text { IUGR, NICU } \\
\text { admission }\end{array}$ & - & $\begin{array}{l}\text { Of two CA, } \\
\text { one shows } \\
\text { infarction }\end{array}$ \\
\hline
\end{tabular}

\section{Discussion}

Placenta is a highly vascular organ involving vasculogenesis and angiogenesis in its development. In the third trimester, terminal villi are developed from the intermediate villi along with capillary loops that represent fetal vessels. Each capillary loop supplies 3 to 5 terminal villi and is sinusoidally dilated in such a way that it reduces the blood flow resistance. This process completes by 28 week. Terminal villous usually contains 2 to 6 capillaries occupying majority of cross section of terminal villi. Any factor that affects angiogenesis of placenta whether maternal or fetal will affect the number of capillaries per villi resulting in VC lesions. ${ }^{[3]}$ In other words, VC lesions are thought to be an adaptive response to injury caused by various associated pre and post-placental risk factors.

Chorangiosis (CH): The prevelance of chorangiosis ranges from 5 to $6 \%$. ${ }^{[2,6]}$ Most cases occur at term. ${ }^{[6,7]}$ In a study by Ogino et al, there were no cases of $\mathrm{CH}$ diagnosed before 32 weeks and were more than 10 -fold common than CA. In the present study, $\mathrm{CH}$ is found in $5.2 \%$ of placenta with majority at more than 34 weeks and they are more than 20-fold common than either CA or CM.

$\mathrm{CH}$ is a diffuse process of hyper vascularity involving terminal villi.

It is thought to be a local adaptation to increase fetal access to maternal oxygen at interhemal membrane. Hypercapillarization may be due to excessive capillary looping due to decoupling stromal and vascular growth. [1] Chorangosis should be differentiated from congestion where the number of capillaries remains normal. ${ }^{[3,8]}$

Risk factors associated with Chorangiosis: There are many maternal, fetal and placental factors associated with chorangiosis that are documented in literature. ${ }^{[1,6,8-10]}$ They are:

Maternal disorders - pre-eclampsia, eclampsia, diabetes, infection (syphilis, UTI), anemia, smoking, jaundice, drug ingestion 
Fetal factors - IUD, IUGR, congenital anomalies, apgar score $<5$

Placental lesions - abruption placenta, placenta previa, amnion nodosum, villitis (due to rubella,syphilis, Bortenella, CMV infection), umblical cord anomalies, placentomegaly

Table 3 shows clinico-pathological profile of $\mathrm{CH}$ in various recent studies. ${ }^{[1,3,6-13]}$ Many feto-maternal factors in the present study correlate with the literature. Rare associations include Tuberculosis, hypothyroidism, oligohydramnios and PROM. So far only one case report each of tuberculosis ${ }^{[9]}$ and hypothyroidism ${ }^{[3]}$ were documented in $\mathrm{CH}$. Also, associations with oligohydramnios and premature rupture of membrane were not reported previously.

To know the clinical significance of associated risk factors in $\mathrm{CH}$, we compared with control placentas without $\mathrm{VC}$ lesions. Since majority of placenta in the study group were beyond 34 weeks of gestation, we took controls that were gestational age matched. After statistical analysis, we found patients with $\mathrm{CH}$ have significant increase in number of LSCS, PROM, Chorioamnionitis and funisitis than controls. (Table 1) Increased incidence of LSCS implies fetal \&/ maternal complications that occurred acutely during delivery while the associations of PROM, chorioamnionitis and funisitis can be attributed to an underlying infective process.

Hypotheses Associated with Chorangiosis: Exact etiology of $\mathrm{CH}$ is unknown. There are various hypothesis described, common among them is hypoxia due to its association with anemia, smokers, high altitude and twin gestation. ${ }^{[1,10]} \mathrm{CH}$ in the present study included two-twin pregnancy and $9(47.4 \%)$ anemic patients. The other hypothesis is related to increased intamural pressure due to venous obstruction at umblical cord or fetal cardiac level. There were no placental factors documented in the present study. An alternative proposal is the associated infection (e.g, bacillary angiosis secondary to bartonella $s p$ ) with increase in local macrophage and its related cytokines like tumor necrosis factor $-\alpha .{ }^{[1,8]}$ Ogino et al noted increased occurance of villitis in placentas with $\mathrm{CH} .{ }^{[1]}$ The present study showed increased incidence of antenatal infections with significant association of PROM, which would have lead to increased number of chorioamnionitis and funisitis (Table 2). Our study correlates more with the infective etiology of $\mathrm{CH}$.

Chorangiosis has been documented even in normal pregnancy. ${ }^{[3]}$ Our study did not include placentas from normal pregnant ladies with no risk factors. The other limitation is the difficulty in interpretation of capillarisation when it is collapsed which depends on mode of delivery, cord clamping, fixatives and time taken to fix the tissue after cessation of umblical circulation. ${ }^{[3]}$

Chorangiomatosis (CM): Uncommon among VC lesions, $\mathrm{CM}$ is a heterogenous, less well-defined lesion with features intermediate between $\mathrm{CA}$ and $\mathrm{CH} .{ }^{[1,10,14]}$ According to Ogino et al, CM shows capillary proliferation involving stem villi surrounding the central core and does not form expansile nodular lesion, however they permeate normal villous structure. ${ }^{[1]} \mathrm{CM}$ can be focal (confined to 1 to 5 villous cross sections), segmental ( $>5$ contiguous villous cross sections) or diffuse multi-focal (multiple independent areas of placenta). ${ }^{[1]}$ Diffuse multifocal CM usually presents with extreme prematurity ( $<32$ weeks) and are associated with IUGR. ${ }^{[15]}$

Table 3 lists recent case studies and case reports of clinical associations ${ }^{[14-18]}$ along with the present case of CM. Like $\mathrm{CH}, \mathrm{CM}$ is associated with feto-maternal complications, common being prematurity, IUGR, pre-eclampsia. ${ }^{[16]}$ In the study by ogino et al, ${ }^{[1]} \mathrm{CM}$ is significantly associated with multiple pregnancy and pre-eclampsia while the diffuse multifocal type correlated with increased number of IUGR and congenital malformations than controls. The one case of diffuse multifocal CM in the present study had associated pre-eclampsia with IUGR baby. CM is thought to represent abnormal capillary proliferation related to feto-placental developmental anomalies and abnormal fetal blood flow. ${ }^{[14]}$

Chorangioma (CA): $\mathrm{CA}$ is the most common benign tumor of placenta, analogous to hemangioma elsewhere with incidence of $<1 \%$. ${ }^{[3,4,19]}$ Their usual location in the placenta is either marginal or subchorionic with gestational age between 32 to 36 weeks. ${ }^{[1]}$ It presents either as expansile nodular mass or an incidental finding at microscopic examination of placenta. CAs are subtyped into nodular and mutinodular. Microscopic features of both include proliferating capillaries, intervening stroma comprised of fibroblast, macrophages, collagen and surrounding trophoblast. ${ }^{[1,4]}$ Occasionally CA can undergo infarction and degenerative changes like hyalinization, myxoid stromal change and calcification. ${ }^{[20]}$ The three histological patterns described by Marchetti were angiomatous, cellular and degenerate, the most common being angiomatous pattern. ${ }^{[19,21]}$ Placenta of the present case showed two nodular masses measuring more than $5 \mathrm{~cm}$ each and histology showed angiomatous type of CA with one showing evidence of infarction.

CA less than $5 \mathrm{~cm}$ usually go unnoticed without any complications. But larger tumors more than $5 \mathrm{~cm}$, called giant $\mathrm{CA}$, acts as an arterio-venous shunt and cause 
distinctive maternal and fetal complications. ${ }^{[22]}$ The incidence of giant $\mathrm{CA}$ ranges from 1:3000 to 1:9000 births. ${ }^{[4,20]}$ Maternal complications include pre-eclampsia, placental abruption, polyhydramnios, preterm delivery and premature rupture of membrane. ${ }^{[3,4]}$ Fetal complications exclusive of giant CA are congestive heart failure, hydrops, hemolytic anemia, thrombocytopenia, congenital anomalies and IUGR. ${ }^{[19]}$

Table 4 highlights the associated complications of CA in various studies in the recent literature. ${ }^{[1,20,22-29]}$ The most common of these complications causing perinatal morbidity are polyhydramnios and preterm delivery, the later being the result of hydramnios. ${ }^{[19]}$ The present study case of giant CA also had polyhydramnios with associated IUGR. The causes of polyhydramnios are multifactorial. It can be because of transudation of fluid into amniotic cavity from the larger vascular area of CA or due to increased intravascular pressure caused by tumor obstructing the vessels near umblical cord insertion or because of functional placental insufficiency due to shunting of blood into the chorangial vascular bed. ${ }^{[25,27]}$ Also, Giant CA acts as physiological dead space leading to chronic hypoxia resulting in fetus growth restriction. ${ }^{[20]}$

Though CA is grouped under benign tumor, they are often thought to be hamartoma or hyperplastic capillary lesion. [20] Several possible etiologies were hypothesized: origin at very early gestation, primary stem villi origin, hypoxia and genetic predisposition ${ }^{[1]}$. In the present study case, occurrence of $\mathrm{CH}$ in present pregnancy following $\mathrm{CA}$ in previous pregnancy in the same patient supports genetic predisposition.

CH vs CM vs CA: Though VC lesions are related entities, they are distinct in their presentation and microscopic features. According to Ogino et al, multiple pregnancy and preeclampsia were found to be more common in $\mathrm{CM}$ and $\mathrm{CA}$ than $\mathrm{CH}$. ${ }^{[1]}$ Histologically, capillary proliferations in $\mathrm{CM}$ involve stem villi sparing the terminal villi, while capillaries in $\mathrm{CH}$ involve terminal villi sparing the stem villi.

To summarize, occurrence of $\mathrm{CH}$ is 20 -fold more common than $\mathrm{CM}$ or $\mathrm{CA}$ with prevalence of $5.2 \%$. Similar to other studies, VC lesions of placenta are commonly associated with complicated pregnancy and neonatal morbidity. When compared with gestational age matched controls, cases with $\mathrm{CH}$ showed significant increase in number of LSCS deliveries, PROM, chorioamnionitis and funisitis that supports the infective etiology of $\mathrm{CH}$. Occurrence of $\mathrm{CH}$ in a patient with $\mathrm{CA}$ in her previous pregnancy reinforces the genetic predisposition among VC lesions. Knowledge on minute distinctions among VC lesions of placenta is essential for accurate diagnosis.

\section{Conclusion}

Thus placental pathology gives important information on the nature of injury it has sustained, as it is a sole organ of contact between mother and fetus. Henceforth, we recommend complete placental examination whenever indicated not only for diagnosis, but also to understand the evolution of the disease process.

\section{Acknowledgement}

Dr.M.Manikandan, Phd, Assistant professor, Department of community medicine in Pondicherry Institute of Medical Sciences for statistical support.

\section{References}

1. Ogino S, Redline RW. Villous capillary lesions of the placenta: distinctions between chorangioma, chorangiomatosis, and chorangiosis. Hum Pathol 2000;31(8):945-54.

2. Altshuler G. Chorangiosis. An important placental sign of neonatal morbidity and mortality. Arch Pathol Lab Med 1984;108(1):71-4.

3. Srinivasan AP, Omprakash BO, Lavanya K, Subbulakshmi Murugesan P, Kandaswamy S. A prospective study of villous capillary lesions in complicated pregnancies. J Pregnancy 2014;2014:193925. doi:10.1155/2014/193925.

4. Fox H, Sebire NJ. Non-trophoblastic tumors of the placenta. In: Fox H, editors. Pathology of the placenta. Philadelphia: Saunders Elsevier; 2007:401-30.

5. Ramasamy J, Varghese RG. Pedunculated Chorangioma of Placenta - an Extremely Rare Case Report. Iran J Pathol 2013;8(4):263-6.

6. Aparna M, Archana J, Vidula G. Chorangiosis of placenta. Report of two cases. Panacea Journal of Medical Sciences 2014;4(2):50-1.

7. Agale SV, Dongaonkar DD. Chorangiosis of placenta. Bombay Hospital Journal 2009;51(2):251-2.

8. Benirschke K, Franciosi R. Placental pathology casebook. J Perinatol 1999;19:393-4.

9. Mathew M, Garg S, Rai L, Kustogi P. Placental Chorangiosis - A report of two cases with unusual associations and review of literature. The Internet Journal of Gynecology and Obstetrics 2008;11(2):1- 3.

10. Soma H, Watanabe Y, Hata T: Chorangiosis and chorangioma in three cohorts of placentas from Nepal, Tibet and Japan. Reprod Fertil Devel 1996;7:1533-8.

11. De La Ossa MM, Cabello-Inchausti B, Robinson MJ. Placental chorangiosis. Arch Pathol Lab Med 2001;125(9):1258.

12. Gupta R, Nigam S, Arora P, Khurana N, Batra S, Mandal AK. Clinico- pathological profile of 12 cases of chorangiosis. Arch Gynecol Obstet 2006;274(1):50-3. 
13. Malathi BG, Manjunath MR. "Chorangiosis Placenta". Journal of Evidence Based Medicine and Healthcare 2014;1(8):922-4.

14. Bagby C, Redline RW. Multifocal Chorangiomatosis. Pediatric and Developmental Pathology 2011;14(1):38-44.

15. Kalli K. Faulkner DO, Blythe B. Bowman MD, Elizabeth Manci MD. Diffuse Multifocal Chorangiomatosis: A Rare Entity With an Unusual Presentation. Am J clin pathol (internet) 2011(cited 2016 feb 15);136:A207. Available from: http://dx.doi.org/10.1093/ajcp/138.supp11.191 A207

16. Chopra A, Iyer VK, Thapar R, Singh N. Diffuse multifocal chorangiomatosis of the placenta with multiple intestinal stenosis of the fetus: combination of rare causes for nonimmune hydrops fetalis. Indian J Pathol Microbiol 2006;49(4):600-2.

17. Gonçalves Baptista Pereira NR, da Rocha Branco MP, Santos Silva MI, et al. Placental vascular lesion as cause of IUGR and nonimmune fetal hydrops in twin pregnancy. Rev Bras Ginecol Obstet 2011; 33(12):421-5 (article in Portuguese, abstract in English)

18. Momeni Boroujeni A, Yousefi E, Vincent MT, Anderson V. Chorangiomatosis: Evaluation of a placental vascular lesion and related clinical effects. Fetal Pediatr Pathol 2014;33(56):331-8.

19. Kodandapani S, Shreshta A, Ramkumar V, Rao L. Chorioangioma of placenta: a rare placental cause for adverse fetal outcome. Case Rep Obstet Gynecol 2012;2012:913878. doi: 10.1155/2012/913878.

20. Adil SAK, Shilpa K, Bharthi M, Anubha A. Giant extraplacental chorangioma: a case report and review. Journal of Evolution of Medical and Dental Sciences 2012;1(4):298-301.
21. Marchetti AA, "A consideration of certain types of benign tumors of the placenta," Surgery, Gynecology \& Obstetrics 1939;68:733-43.

22. Chen CP, Chern SR, Wang TY, Huang ZD, Huang MC, Chuang CY. Pregnancy with concomitant chorangioma and placental vascular malformation with mesenchymal hyperplasia. Human Reproduction 1997;12(11):2553-6.

23. Lez C, Fures R, Hrgovic Z, Belina S, Fajdic J, Munstedt K. Chorangioma placentae. Rare Tumors 2010; 2(4): e67. doi: 10.4081/rt.2010.e67.

24. Tihonenko I. Chorioangioma. Thefetus.net (internet) 2012 (cited 2016 feb 5); (about 8 p). Available from: http://www. sonoworld.com/fetus/page.aspx?id=3114

25. Lokuhetty D, Al Bahari M. Successful Outcome of a Pregnancy Complicated by a Voluminous Placental Chorangioma: Case report with Review of the Literature. Oman Med J (internet) 2014 May (cited 2016 feb 5); 29(4). (about 4 p). Available from: http://www.omjournal.org/ fultext_PDF.aspx?DetailsID=587\&type=fultext

26. Andola US, Karangadan S, Andola SK, Jewargikar R. Chorangioma of Placenta with High Risk Pregnancy: A Case Series. Journal of Basic and Clinical Reproductive Sciences 2014;3(1):71-3.

27. Abdalla N, Bachanek M, Trojanowski S, Cendrowski K, Sawicki W. Placental tumor (chorioangioma) as a cause of polyhydramnios: a case report. International Journal of Women's Health 2014;6:955-9.

28. Singh S, Garg S, Verma R, Chandana A, Sen R, Ralli M. Journal of Gynecologic Surgery 2015;31(1): 26-8.

29. Sahu KK, Rau A, Suresh PK. Utility of reticulin stain in the diagnosis of a completely infarcted chorangioma. Medical Journal of Dr. D.Y. Patil University 2016;9:95-7.

*Corresponding author:

Dr Niraimathi Manickam, Department of Pathology, Pondicherry Institute of Medical Sciences, Ganapathichettikulam, Puducherry-605004, India. Phone: +917339065370

Email: niraimathi.md@gmail.com

Financial or other Competing Interests: None. 